\title{
WAKAF DAN KEMANDIRIAN PESANTREN DARI TEBUIRENG HINGGA GONTOR
}

\author{
Miftahul Huda \\ STAIN Ponorogo, Jl. Pramuka No. 156 Ronowijayan, \\ elhoeda@yahoo.com
}

\begin{abstract}
This paper focuses on the notion of endowment and its role in the building and development of pesantren in Indonesia. It is interested particularly in investigating the economically independent nature of pesantren through the scheme of endowment. It also traces the history of pesantren to show that it has been independent all along. Its independence, the paper argues expands not only in economic terms but also in academic, theological as well as intellectual realm. Even against the onslaught of modernity, pesantren has been independent in the sense that it has not fallen prey to the negative impacts of modernity, if any. This paper discusses this as well as the strategy of pesantren in dealing with modernity particularly by referring to the experience of two great pesantrens, namely Tebuireng and Gontor. The paper keeps in mind that it is the values of the two pesantrens that kept them intact from the influence of modernity. It investigates therefore the nature and kind of these values as well the extent to which the two pesantrens are attached to them. One of the values that the paper is interested in is the notion of charity (sadaqah), the some-what equivalent word for endowment (waqf).
\end{abstract}

Keywords: Charity, endowment, nâżir, modernity, pesantren.

\section{Pendahuluan}

Pesantren, sebagai sistem pendidikan pribumi yang memiliki latar budaya dan sosial, semenjak kemunculannya mudah diterima dan kemudian mengakar kuat di dalam masyarakat Indonesia. ${ }^{1}$ Karena pesantren merepresentasikan pendidikan unik yang mensintesakan dimensi sosial, budaya dan agama, maka sintesis ini kemudian mempengaruhi fungsi pesantren baik secara internal maupun

1 Ismail SM, et al. (ed.), Dinamika Pesantren dan Madrasab (Yogyakarta: Pustaka Pelajar, 2002), xiv. 
eksternal. Pesantren kemudian muncul sebagai sebuah komunitas yang memiliki kemampuan untuk terlibat dalam aktivitas-aktivitas kreatif dalam pembangunan masyarakat dengan menggunakan pendidikan alternatif yang menggabungkan pendidikan dan pengajaran. $^{2}$

Wacana tentang fungsi sosial pesantren diperlukan dengan menimbang ulang peranan dan dinamika pesantren dalam masyarakat Indonesia modern, di mana dinamika modernitas mempengaruhi secara fundamental keberadaan pesantren sehingga mengakibatkan munculnya problem identitas kultural pesantren. Problem ini dapat dianggap sebagai konsekuensi dan implikasi logis ketika berhubungan dengan modernitas yang memiliki keharusan yang mempengaruhi secara khusus fungsi sosial dan budaya yang didasari atas kewajiban keagamaan. Akibatnya, modernitas memberi tantangan secara langsung terhadap asumsi tradisional dari dunia pesantren. Oleh sebab itu, sudah saatnya pesantren memikirkan kembali misi otentik dan peranannya di tengah-tengah masyarakat Indonesia. Modernitas sendiri membawa implikasi perubahan-perubahan dalam banyak aspek kehidupan, khususnya institusi agama seperti pesantren itu sendiri.

Dalam merespons modernitas, aktivitas yang dilakukan pesantren selama ini adalah dengan mengembangkan perekonomian guna membiayai kelangsungan roda dan program kehidupan pesantren. Dengan situasi apapun pesantren, sebagai bagian dari sub kultur masyarakat, tetap eksis walaupun dengan swadaya. ${ }^{3}$ Kemampuan kiai, para ustaz, santri, dan masyarakat sekitar, menjadi kunci utama untuk meneguhkan atau setidaknya meningkatkan kompetensi pesantren dalam visinya itu. Tetapi, kenyataannya banyak pesantren yang merasa kesulitan pendanaan dan mulai berfikir ulang dalam rangka meningkatkan kemampuan finansialnya, dan acapkali menjadi masalah serius sehingga membuat pesantren kurang dapat melaksanakan visi dan program utamanya. Apalagi, biasanya, pesantren sangat bergantung pada sumber dana tertentu, seperti pendapatan dari iuran santri yang berdampak pesantren kurang berkembang dengan cepat sesuai harapan. Pendanaan memang menjadi masalah dan tantangan

2 Soetjipto Wirosardjono, The Impact of Pesantren in Education and Community Development in Indonesia (Berlin: Fredrich-Naumann Stiftung Indonesian Society for Pesantren and Community Development (P3M), and Technical University Berlin, 1987), 218.

${ }^{3}$ Ismail SM, et al. (ed.), Dinamike Pesantren, xiv. 
besar bagi pengembangan sebagian lembaga pesantren di Indonesia, padahal potensi yang ada dalam komunitas pesantren dan ekonomi sebenarnya cukup besar. ${ }^{4}$

Dari berbagai fakta di atas, perlu upaya lebih serius untuk mendorong berkembangnya program mobilisasi sumber daya khususnya dari sumber daya mayarakat, untuk mendukung program dan aktivitas yang dilakukan oleh pondok pesantren. Salah satu upaya urgen yang dilakukan adalah mendokumentasikan pengalaman dari beberapa pesantren yang berhasil dalam memobilisasi sumber daya dari sumber-sumber wakaf. Pesantren tersebut adalah Pesantren Tebuireng Jombang dan Pesantren Darussalam Gontor Ponorogo yang dijadikan case study dalam artikel ini. Pengalaman mereka juga bisa digunakan sebagai media untuk menyakinkan lembaga pondok pesantren untuk lebih meningkatkan kemampuan dalam mengelola wakaf. Hal ini, secara tidak langsung akan semakin meningkatkan eksistensi pesantren sebagai sub kultur yang tidak bisa dipisahkan dari masyarakat. Karena itu tulisan ini berusaha mengilustrasikan tentang bagaimana ikhtiyar pesantren menjaga semangat kemandiriannya ketika berhadapan dengan pengaruh kehidupan modern dan mengukuhkan keberlanjutan misinya agar dapat memainkan peran sebagai masyarakat madani dalam konteks Indonesia modern.

Untuk itulah tulisan ini diawali dengan deskripsi tentang konsepsi wakaf dan kemandirian pesantren, profil Pesantren Tebuireng dan Gontor dalam mengelola wakaf, dan pesantren wakaf sebagai model kemandirian pesantren era Indonesia kontemporer.

\section{Esensi Wakaf dan Kemandirian Pesantren}

Wakaf memiliki akar teologis yang kuat. Al-Qur'an, meskipun tidak menyebutkan secara eksplisit istilah wakaf, jelas mengajarkan signifikansi kedermawanan sosial untuk berbagai tujuan yang baik. ${ }^{5}$ Hadith Nabi dan praktik sahabat menunjukkan bahwa wakaf merupakan bagian dari ajaran Islam. Namun dalam perkembangannya, institusi wakaf tidak bisa dilepaskan dari dinamika sosial, ekonomi, budaya yang mengiringi perkembangan masyarakat Islam dari masa ke masa. Wakaf dalam bentuk yang sederhana telah

4 A. Halim, "Menggali Potensi Ekonomi Pondok Pesantren", dalam A. Halim et al., Manajemen Pesantren (Yogyakarta: Pustaka Pesantren, 2005), 222.

5 Dalam al-Qur'ân, "wakaf" yang dimaknai sebagai suatu perbuatan berderma sejatinya merupakan bagian dari esensi filantropi seperti konsep khayr, konsep infâq, dan konsep birr. Lihat al-Qur'ân, 22: 77; al-Qur'ân, 2: 267; al-Qur'ân, 3: 97. 
dipraktikkan para sahabat atas petunjuk Nabi. Salah satu riwayat yang menjadi dasar praktik wakaf pada masa awal Islam adalah hadîth Ibn 'Umar. Hadîth ini mengisahkan sahabat 'Umar b. Khațtâb yang mendapatkan sebidang lahan di daerah subur Khaibar dekat Makkah. 'Umar yang hendak bersedekah dengan lahan ini menanyakan kepada Nabi perihal niatnya tersebut, dan Nabi bersabda, "jika engkau bersedia tahan asalnya dan sedekahkan hasilnya" .

Ungkapan Nabi di atas pada gilirannya menjadi landasan normatif dan doktrinal wakaf. Hadîth itulah kemudian menjadi substansi dari definisi wakaf yaitu, menahan asal dan mengalirkan hasilnya. Adapun pemilihan makna ini, al-Kabisi mengungkapkan argumentasinya: pertama, makna wakaf di atas langsung dikutip dari hadîth Nabi kepada 'Umar. Nabi adalah orang yang paling benar ucapannya dan yang paling sempurna penjelasannya dan yang paling mengerti akan sabdanya. Kedua, pemaknaan ini tidak ditentang oleh berbagai pendapat mazhab fiqh. Ketiga, makna ini hanya membatasi pada hakikat wakaf saja dan tidak mengandung perincian yang dapat mencakup definisi lain, seperti niat taqarrub kepada Allah, status kepemilikan, konteks waktu dan sebagainya.

Landasan hadîth ini melahirkan, setidaknya, lima prinsip umum yang membentuk kerangka konsepsual dan praktik wakaf. Pertama, kedudukan wakaf sebagai sedekah sunnah yang berbeda dengan zakat. Kedua, kelanggengan aset wakaf, sehingga harta wakaf tidak boleh diperjualbelikan, diwariskan maupun disumbangkan. Ketiga, keniscayaan aset wakaf untuk dikelola secara produktif. Keempat,

${ }^{6}$ Diriwayatkan dengan berbagai redaksi yang hampir sama oleh Bukhârî (1987: II/840), Muslim (III: 1255-1256), Tirmîdhî (II: 417, Abû Dâwud (III: 116-117, Ibn Mâjah (II: 801) dan al-Nasâ’î (1420 H:VI/230-232). Lebih lengkapnya lihat Ibrâhîm Maḥmûd 'Abd al-Bâqî, Dawr al-Waqf fì Tanmîyat al-Mujtama' al-Madanî: Namûdhaj alAmânah al-'Ámmah li al-Awqâf bi Dawlah al-Kuwayt) (Kuwait: al-Amânah al 'Âmmah li al-Awqâf Idârah al-Dirâsah wa al-'Alâqat al-Khârijîyah, 2006), 16. Adapun redaksinya adalah:

حدثنا قتيبة بن سعيد حدثنا محمد بن عبد الله الأنصاري حدثنا ابن عون قال أنبأني نافع عن ابن عمر رضي

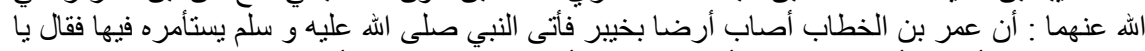

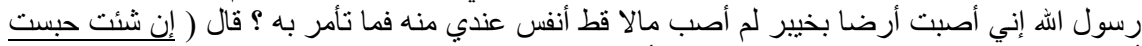

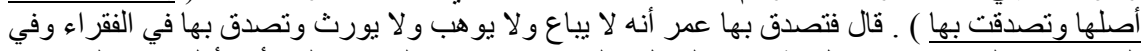

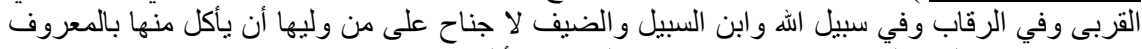

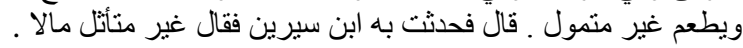

7 Muhammad Abid Abdullah al-Kabisi, Hukum Wakaf (Jakarta: IIMaN Press, 2004), 61-62. 
keharuskan menyedekahkan hasil wakaf untuk berbagai tujuan yang baik. Kelima, diperbolehkannya nâz̧ir wakaf mendapatkan bagian yang wajar dari hasil wakaf. ${ }^{8}$

Qahaf merangkum dari berbagai pendefinisian tentang wakaf, dengan menyebutkan beberapa inti dari wakaf, yaitu: pertama, menahan harta untuk dikomsumsi atau dipergunakan secara pribadi. Ini menunjukkan bahwa wakaf berasal dari modal yang bernilai ekonomis dan bisa memberikan kemanfaatan ekstensif untuk tujuan tertentu. Kedua, definisi wakaf mencakup harta, baik harta bergerak maupun tidak bergerak atau adanya manfaat dari mengkapitalisir harta non-finansial. Ketiga, mengandung pengertian melestarikan harta dan menjaga keutuhannya sehingga memungkinkan untuk dimanfaatkan secara langsung atau diambil manfaat hasilnya secara berulang-ulang. Keempat, berulang-ulangnya manfaat dan kelanjutannya baik yang bersifat sementara maupun selama-lamanya. Kelima, definisi wakaf ini mencakup wakaf langsung, yang menghasilkan manfaat langsung dari harta wakaf, atau juga wakaf produktif yang memberi manfaat dari hasil produksinya, baik berupa barang maupun jasa serta menyalurkannya sesuai dengan tujuan wakaf. Keenam, mencakup jalan kebaikan umum keagamaan, sosial dan lainnya. Ketujuh, mencakup pentingnya penjagaan dan kemungkinan bisa diambil manfaatnya secara langsung atau dari manfaat hasilnya.'

Hakikat wakaf di atas menunjukkan bahwa wakaf harus produktif dan memberikan kemanfaatan yang ekstensif, maka dibutuhkan fungsi-fungsi pengelolaan dan organisasi yang mandiri dan berkelanjutan. Karena itu, wakaf harus dikelola dengan manajemen yang baik.

Wakaf adalah termasuk salah satu model filantropi yang ditawarkan dalam Islam. Wakaf dikenal dapat berfungsi memberdayakan ekonomi umat. Instrumen wakaf begitu besar bagi masyarakat Muslim, baik dulu, saat ini, maupun akan datang, sebagai model dan pola peningkatan kesejahteraan umat. Wakaf sendiri berarti menahan harta yang dapat diambil manfaatnya tanpa musnah dan untuk penggunaan yang mubah, serta dimaksudkan untuk mendapatkan keridhaan Allah atau dengan kalimat lain, wakaf ialah

8 Tuti A. Nadjib \& Ridwal Al-Makassary, Wakaf, Tuban, dan Agenda Kemanusiaan (Jakarta: CSRS UIN Jakarta, 2006), 30.

${ }^{9}$ Mundhîr Qahaf, al-Waqf al-Islâmî: Tatammuruh, Idâratub, Tanmiyatuh (Damaskus: Dâr al-Fikr, 2006), 52-54. 
menahan asal dan mengalirkan hasilnya. ${ }^{10}$ Dengan cara demikian, harta wakaf dapat dipergunakan untuk kepentingan publik dan kemaslahatan umum secara berkesinambungan tanpa menghilangkan harta asal. Hukum-hukum yang menyangkut pengelolaan wakaf, di samping peribadatan dan perorangan, dilaksanakan secara konsisten di kalangan umat Islam. Semangat berwakaf ini pada zaman klasik terbukti mampu menciptakan suasana kondusif untuk bangkitnya intelektualisme Muslim sehingga Islam mencapai puncak kegemilangannya.

Di beberapa negara seperti Mesir, Yordania, Saudi Arabia, Turki, Kuwait, wakaf selain berupa sarana dan prasarana ibadah dan pendidikan juga berupa tanah pertanian, perkebunan, flat, hotel, pusat perbelanjaan, uang, saham, real estate dan lain-lain yang semuanya dikelola secara produktif. Dengan demikian hasilnya benar-benar dapat dipergunakan untuk mewujudkan kesejahteraan umat. Sepanjang sejarah Islam, wakaf telah berkontribusi penting dalam pengembangan kegiatan-kegiatan sosial, ekonomi dan kebudayaan masyarakat Islam serta telah menyokong sarjana dan mahasiswa dengan infra struktur yang memadai yang memungkinkan mereka melakukan berbagai kegiatan untuk menyelesaikan studi mereka. Cukup banyak program-program yang didanai dari hasil wakaf seperti penelitian buku, penerjemahan dan kegiatan-kegiatan ilmiah dalam berbagai bidang, termasuk bidang kesehatan. Wakaf tidak hanya mendukung pengembangan ilmu pengetahuan tetapi juga menyediakan berbagai fasilitas yang diperlukan mahasiswa maupun masyarakat. Sebagai contoh misalnya di bidang kesehatan, lembaga wakaf juga menyediakan fasilitas-fasilitas untuk meningkatan kesehatan masyarakat dan fasilitas pendidikan dengan pembangunan rumah sakit, sekolah medis, dan pembangunan industri obat-obatan serta kimia.

Dalam konteks Indonesia, keberadaan wakaf, khususnya wakaf tanah, sudah dilakukan semenjak lahirnya komunitas-komunitas Muslim. Lembaga wakaf muncul bersamaan dengan lahirnya masyarakat Muslim, sebagai sebuah komunitas pada umumnya memerlukan fasilitas-fasilitas peribadatan dan pendidikan untuk menjamin kelangsungannya sebagaimana cikal bakal pondok

10 Muḥammad Muṣtafâ Shalabî, Mụ̣ậarah fî al-Waqf wa al-Wasîyab (Iskandarîyah: t.p., 1957), 19. 
pesantren. Fasilitas-fasilitas itu dapat terpenuhi dengan cara wakaf, baik berupa tanah, bahan bangunan, maupun sumbangan tenaga.

Dalam konteks inilah, sangat penting apabila mengaitkan aktivitas pengelolaan dan pengembangan wakaf dengan institusi pesantren. Peran nâżir wakaf pesantren saat ini sungguh dibutuhkan untuk memobilisasi kerjanya. Adapun starting point dalam pengelolaan wakaf yang produktif adalah cara mengumpulkan atau menggalang sumber wakaf. Dengan ini, diharapkan institusi wakaf mempunyai signifikansi dalam meneguhkan kemandirian dan ikhtiyar pencapaian visi pesantren. Artinya dukungan finansial maupun non-finansial akan sangat berguna bagi kelangsungan pesantren.

\section{Potret Pesantren Wakaf: Pesantren Tebuireng Jombang}

Tradisi wakaf di Pesantren Tebuireng Jombang, khususnya wakaf persawahan/padi, telah dijalankan jauh sebelum wakaf dilembagakan dan dikelola secara resmi. Di pesantren ini, wakaf awalnya, yang hanya terdiri dari 13 ha tanah, diserahkan untuk pertama kalinya tahun 1946 oleh pendiri pondok K.H. Hasyim Asy'ari, tidak lama sebelum sang wâqif meninggal dunia, setelah beliau wafat, para Kiai Tebuireng berikutnya menjalankan tradisi sebagai nâżir wakaf. Pada saat akad penyerahan wakaf dilakukan, ikrar wakaf tidak memiliki legalitas formal karena pada masa itu akta wakaf belum dikenal. Sebagaimana yang disampaikan Muhsin KS, pengelolaan harta wakaf pada awalnya, dilakukan secara personal oleh nâz̧ir yang dengan menunjuk beberapa orang kepercayaannya di kampung-kampung terdekat untuk mengurusi sawah-sawah pondok. Karena tidak adanya mekanisme kontrol yang memadai, maka hasil wakaf yang ada jauh dari cukup untuk dimanfaatkan bagi pengembangan aktivitas pendidikan pesantren.

Sementara wakaf masih dijalankan secara tradisional, proses pendidikan di pesantren karena adanya tuntutan perkembangan modern, mengalami perubahan yang berarti. Para pengelola pesantren Tebuireng sementara terus memelihara metode pendidikan dan pengajaran tradisonal dari waktu ke waktu sembari mengadopsi metode pendidikan modern dalam bentuk sekolah formal, baik sekolah agama maupun sekolah umum. Perubahan ini berlangsung tanpa dibarengi dengan upaya yang serius untuk mengoptimalkan 
wakaf sebagai sumber dana yang vital untuk menopang program pengajaran dalam rangka memelihara tradisi kemandirian pesantren. ${ }^{11}$

K.H. Hasyim Asy'ari menyadari betul siginifikansi dan peran yang dapat dimainkan oleh institusi wakaf untuk menjamin kelangsungan hidup pesantren dan proses pendidikan di dalamnya. Dari hasil wakaf inilah kiai beserta keluarganya, para badal (asisten kiai), guru-guru dan beberapa santri yang tidak mampu dapat memenuhi kebutuhan hidupnya. Kiai Hasyim membuktikan kesadarannya itu dengan menyerahkan tanah-tanahnya sebagai wakaf kepada pondok. Ini juga mencerminkan nilai pengorbanan dan keikhlasan yang merupakan norma-norma tradisional yang dipegang teguh oleh komunitas pesantren dengan kiai sebagai teladan utamanya. Tentu saja pada masa awal belum terpikir oleh kiai perlunya menggalang dana wakaf dari masyarakat untuk pembangunan pesantren. Tidak jelas apa alasannya, tapi besar kemungkinan belum muncul tantangan yang nyata yang memberikan stimulus bagi tuntutan ke arah sana.

Kesadaran pelembagaan wakaf pada akhir-akhir ini mencoba untuk digalakkan, apalagi semenjak Gus Sholah (panggilan K.H. Salahuddin Wahid) menjadi pengasuh Pesantren Tebuireng. Sebenarnya, pengembangan wakaf secara terbatas telah dimulai sejak masa-masa awal setelah berdirinya pondok. Namun, tanah-tanah wakaf sawah yang ada dipercayakan untuk dikelola oleh orang-orang kampung, biasanya tergolong kaya dan termasuk alumni pondok. Ini tentu saja didorong oleh pertimbangan praktis bahwa kiai dan para badal-nya tidak sempat mengelola sawah, sementara mereka harus menjalankan fungsi utamanya mengurus pesantren dan memberikan bimbingan keagamaan kepada para santri. Kerjasama dibangun berdasarkan kepercayaan tanpa adanya mekanisme kontrol yang memadai dari pesantren selaku nâz̧ir atau pengelola wakaf. Akibatnya dirasakan hasil wakaf tidak maksimal, di mana pondok diberikan bagian seadanya. Tidak terdapat kejelasan dan kepastian mengenai pola-pola kerjasama yang saling menguntungkan antara kedua belah pihak. Maka, pada tahun 1982 diputuskan untuk menarik kembali semua pengelolaan tanah sawah dari orang-orang desa dan diserahkan untuk dikontrol sepenuhnya oleh pesantren. Sejak saat itu sawahsawah wakaf yang umumnya dipakai untuk menanam Tebu mulai

11 Chaider S. Bamualim \& Irfan Abubakar (ed.), Revitalisasi Filantropi Islam: Studi Kasus Lembaga Zakat dan Wakaf di Indonesia (Jakarta: PBB UIN Syarif Hidayatullah dan Ford Foundation, 2005), 285. 
dikelola dengan baik dan dapat menghasilkan keuntungan yang lebih besar, begitu juga dengan tanaman padi dapat dipanen empat kali dalam setahun. Ini tentunya membantu memperbaiki kondisi keuangan pondok.

Dalam konteks yang lebih luas nâżir wakaf didirikan untuk menopang upaya-upaya transformasi kehidupan sosial dan keagamaan masyarakat Muslim Indonesia melalui aktivitas pendidikan yang bersandar pada prinsip kemandirian masyarakat madani. Tujuan visi dan misi nâżir wakaf dirumuskan dengan mengacu pertama kepada tanggung jawab normatif kaum Muslimin yang dituntut oleh ajaran Islam, yaitu menyebarkan ajaran Islam dan atas dasar itu berupaya menciptakan sebuah masyarakat yang sejahtera lahir dan batin, dunia dan akhirat. Kerangka ideal ini juga diarahkan oleh pemahaman dan kesadaran para pendiri dan pengelola pesantren terhadap perubahan sosial dan keagamaan dalam masyarakat Islam pasca kolonial. Sebagai pemimpin umat mereka ingin memainkan peran apapun yang dapat mereka lakukan untuk mengarahkan perubahan ini sesuai dengan nilai-nilai Islam.

Di Pesantren Tebuireng, secara kelembagaan, nâżir wakaf adalah bagian kecil dari Yayasan Hasyim Asy'ari, berkedudukan di bawah yayasan dan lebih memfokuskan untuk mengurus pengelolaan harta wakaf termasuk memelihara, memperluas wakaf yang ada, mengatur pemanfaatannya, dan mengurus sertifikat dan hal-hal yang menyangkut kepastian hukum benda wakaf yang ada.

Dari segi manajemen organisasi tampak bahwa meskipun pengelola nâzzir wakaf Tebuireng menyadari pentingnya wakaf dikelola secara kelembagaan, namun dalam praktiknya mereka sendiri dalam taraf berusaha atau berproses menjalankan fungsi manajemen modern, termasuk perencanaan pengembangan wakaf dan sistem evaluasi terhadap kinerja organisasi. Pada umumnya program dijalankan secara alamiah dan lebih menekankan orientasi jangka pendek. Alasan yang acap dikemukakan adalah kurangnya sumber daya manusia yang cakap di bidang menajemen sekaligus dapat menyesuaikan diri dengan situasi dan kondisi pondok pesantren.

Karena keterbatasan sumber daya manusia tersebut, ketua nâģir wakaf merangkap ketua yayasan sekaligus pengasuh pesantren. Ketua dibantu oleh sekretaris, bendahara dan beberapa staf yang dalam kepentingan wakaf tertentu juga mengurusi legalitas wakaf langsung seperti sertifikat tanah wakaf dan sebagainya. Semua aspek 
menyangkut pengelolaan wakaf dilaporkan oleh koordinator wakaf kepada ketua nâżir wakaf. Kenyataannya, urusan wakaf keseharian sering didelegasaikan kepada orang kepercayaannya yang juga pengurus yayasan sekaligus nâżir seperti sekretaris atau bendaharanya. Di sini faktor kepercayaan individu lebih ditekankan ketimbang pertimbangan fungsi dan peran dalam struktur formal keorganisasian.

Aset tanah wakaf Pondok Pesantren Tebuireng sampai tahun 2008 adalah $405.824 \mathrm{~m} 2$ atau 40,582 Ha, dengan terbagi menjadi dua periode yaitu wâqif dari K.H. Hasyim Asy'ari dan periode setelahnya (lihat tabel 1). Sedangkan dalam bentuk wakaf dengan uang, sampai April 2010 dilihat dari neraca keuangan total pembangunan Yayasan Hasyim Asy'ari Pesantren Tebuireng adalah sebesar 10.842.646.568,00, dengan aset wakaf melalui uang di dalamnya sejumlah kurang lebih 6.480.294.000,00. Dari dana wakaf berupa uang tunai tersebut sebagian besar diwujudkan untuk pengembangan pendidikan dan pesantren, sebagian lagi digunakan untuk investasi dan pengembangan aset wakaf.

Di samping penambahan luas tanah wakaf, nâżir wakaf Tebuireng juga merealisasikan dan mewujudkan wakaf dalam bentuk bangunan yang mulai dirancang dan direalisasikan pada masa kepengasuhan Gus Sholah seperti masjid, asrama pesantren, madrasah dan sekolah serta gedung kompleks multy purpose seperti komplek Suryo Kusumo, Komplek Haji Kalla, Saefuddin Zuhri, Sholehah Wahid dan sebagainya. Pembangunan gedung ini berasal dari para wâqif, baik dalam bentuk bangunan gedung langsung ataupun berupa uang yang diwujudkan dalam bentuk gedung oleh nâżir wakaf Tebuireng.

Tabel 1

Aset Tanah Wakaf Yayasan Hasyim Asy'ari Pesantren Tebuireng Jombang

\begin{tabular}{|c|l|c|l|}
\hline No & \multicolumn{1}{|c|}{ Wakif } & Luas Tanah & \multicolumn{1}{|c|}{ Keterangan } \\
\hline 1 & K.H. Hasyim Asy'ari & $137.850 \mathrm{M} 2$ & $\begin{array}{l}\text { Kompleks pondok dan } \\
\text { sawah }\end{array}$ \\
\hline 2 & Wakif Masyarakat & $149.532 \mathrm{M} 2$ & $\begin{array}{l}\text { Lapangan sekitar pondok } \\
\text { dan beberapa sawah dan } \\
\text { pekarangan di luar pondok }\end{array}$ \\
\hline 3 & $\begin{array}{l}\text { Pembelian dan } \\
\text { Diatasnamakan } \\
\text { Wakaf Tebuireng }\end{array}$ & $118.436 \mathrm{M} 2$ & $\begin{array}{l}\text { Beberapa areal bangunan } \\
\text { madrasah dan sekolah serta } \\
\text { sawah di luar Tebuireng }\end{array}$ \\
\hline \multicolumn{2}{|c|}{ Total } & $405.824 \mathrm{M} 2$ \\
\hline
\end{tabular}




\section{Potret Pesantren Wakaf: Pesantren Darussalam Gontor}

Dalam Badan Wakaf Pondok Modern Gontor, ikrar wakaf sebenarnya telah terjadi sejak tahun 1951, bertepatan dengan ulang tahun seperempat abad pondok pesantren ini. Pada tahun itu, telah diucapkan semacam ikrar bahwa pondok Modern Gontor milik seluruh umat Islam dan bahwa maju mundurnya pondok tergantung kepada kesadaran umat Islam sendiri sebagai pemiliknya. Namun karena penyerahan ini belum memiliki kekuatan legal formal, banyak pihak yang meragukan keabsahan ikrar tersebut. Maka dalam rangka memenuhi legalitas tersebut, pada tanggal 12 Oktober 1958, wâqif atas nama pendiri Pondok Modern Gontor yang biasa dipanggil "Trimurti", menandatangani piagam penyerahan wakaf Pondok Modern Gontor Ponorogo kepada 15 wakil dari Ikatan Keluarga Pondok Modern (IKPM), yang merupakan alumni Pondok Modern Gontor.

Harta wakaf yang diserahkan pada saat tu terdiri dari tanah basah atau sawah $(1,74 \mathrm{Ha})$, tanah kering $(16,85 \mathrm{ha})$ dan 12 gedung serta perlengkapannya. Harta wakaf tersebut sebagiannya berasal dari peninggalan orang tua Trimurti, sedangkan sebagian lainnya diperoleh dari bantuan masyarakat yang bersimpati kepada Pondok. Apalagi sejak tahun 1931 PM Gontor telah membentuk Kbizânah, sebuah badan khusus yang bertugas melakukan penggalangan dana yang hasilnya kemudian dibelikan sawah.

Selain untuk tujuan beribadah, ada beberapa alasan yang menggerakkan Trimurti secara sukarela mewakafkan harta bendanya. Para pendiri pondok tentu sangat prihatin dengan kenyataan bahwa pada masa lalu, jarang ada pesantren yang bertahan lama sepeninggal pendirinya. Ini karena pesantren itu pada umumnya milik kiai dan apabila sang kiai wafat maka akan digantikan oleh puteranya dan kemudian keturunannya. Di sisi lain, pesantren sangat tergantung pada kharisma sang kiai. Akibatnya apabila tidak ada keturunan kiai yang mumpuni dan karismatik, maka pesantren akan kehilangan dukungan masyarakat, dan pada gilirannya akan sulit bertahan sepeninggal sang pendiri. Inilah realitas yang menimpa kebanyakan pesantren besar masa lalu. ${ }^{12}$

\footnotetext{
12 Tim Penulisan Riwayat Hidup dan Perjuangan K.H. Imam Zarkasyi, Biografi K.H. Imam Zarkasyi: Dari Gontor Merintis Pesantren Modern (Ponorogo: Gontor Press, 1996), 77-78.
} 
Alasan lainnya adalah tidak ada kepastian hukum mengenai kepemilikan tanah atau harta benda pesantren. Sering tidak ada batas pemisah yang jelas antara hak milik pesantren dan hak milik keluarga kiai, yang pada tataran selanjutnya menimbulkan konflik dan keributan. Konflik internal ini biasanya timbul karena tidak adanya sebuah sistem yang dapat mengelola dengan baik antara kepentingan keluarga dan pondok. Trimurti tampaknya melihat bahwa intitusi wakaf dapat menjadi alat yang tepat guna mengatasi konflik yang mungkin timbul di kemudian hari. Apalagi intitusi wakaf dalam sejarah Islam, sangat besar pengaruh dan manfaatnya seperti universitas Al-Azhar Mesir ataupun universitas Islam di era keemasan Islam.

Visi dan misi badan wakaf Gontor ada lima butir penting yang merupakan amanat Trimurti kepada badan wakaf selaku nâz̧ir. Pertama, pondok modern ini harus tetap menjadi kegiatan sosial keagamaan (amal jâriyah), yang tunduk kepada aturan dalam agama Islam. Kedua, Pondok modern harus tetap menjadi sumber ilmu-ilmu agama, ilmu umum, bahasa Arab, namun berjiwa pesantren. Ketiga, Pondok modern ini adalah lembaga pengabdian masyarakat dalam artian membentuk karakter umat guna kesejahteraan lahir dan batin. Keempat, Pondok modern harus dipelihara dan dikembangkan agar kelak menjadi sebuah universitas Islam yang bermutu dan berarti. Kelima, untuk menjamin agar amanat tersebut memiliki kekuatan hukum formal, maka badan wakaf harus segera mempunyai akta notaris. ${ }^{13}$

Tidak seperti kebanyakan lembaga pengelola wakaf atau nâżir di Indonesia. Badan Wakaf PM Gontor tidak langsung mengurus, memelihara dan memperluas harta wakaf, tapi mendelegasikan wewenang tersebut kepada pimpinan pondok sebagai mandatarisnya. Dalam struktur organisasai Balai Pendidikan Gontor, Badan Wakaf menempati kedudukan tertinggi sebagai lembaga legislatif yang memiliki tugas dan wewenang yang luas. Lembaga ini berfungsi memutuskan dan menetapkan kebijakan yang terkait dengan semua proses pendidikan di Pondok, menetapkan visi dan misi, aturanaturan dan statuta lembaga di bawahnya, serta memilih dan menetapkan pimpinan pondok serta pimpinan lembaga di bawahnya. 14

\footnotetext{
13 Pondok Modern Gontor, Sedjarah Balai Pendidikan Pondok Modern Gontor Ponorogo (Ponorogo: t.p., t.th), 236-237.

${ }^{14}$ Bamualim \& Abubakar (ed.), Revitalisasi, 220.
} 
Karena kewenangannya yang sangat luas maka badan wakaf selalu mendiskusikan tentang kelembagaan secara keseluruhan yang mencakup: pertama, KMI (Kulliyat Mualllimin al-Islamiyah), yaitu lembaga perguruan setingkat Tsanawiyah dan Aliyah dengan masa belajar 4-6 tahun, kedua, lembaga perguruan tinggi yang disebut ISID (Institut Studi Islam Darussalam), ketiga, lembaga pengasuhan santri, keempat, Yayasan Pemeliharaan dan Perluasan Wakaf Pondok Modern (YPPWPM), dan bagian inilah yang menjadi ujung tombak pengelolaan badan wakaf Gontor, serta kelima IKPM (Ikatan Keluarga Pondok Modern). ${ }^{15}$

YPPWPM didirikan pada tanggal 18 Maret 1959, setahun setelah pelaksanaan ikrar wakaf, sesuai pasal 7 ART Badan Wakaf, yayasan ini bertanggung jawab atas pembiayaan dan pemeliharaan Balai Pendidikan Pondok Modern Gontor dengan segala milik dan kekayaannya. Dalam mengelola tanah-tanah sawah wakafnya, yayasan ini dibantu oleh para pengawas yang juga disebut nâżir. Para nâżir ini berasal dari daerah tempat sawah tersebut berada. Mereka bertanggung jawab kepada yayasan dan kedua belah pihak biasa melakukan evaluasi bersama. Tugas lainnya yaitu mengusahakan kepastian hukum tanah-tanah wakaf milik pesantren dengan cara menyertifikasinya sesuai aturan yang ada. ${ }^{16}$

Selain mengintensifkan pengurusan tanah wakaf, yayasan ini juga menggali dana-dana dari luar hasil tanah wakaf, baik yang diperoleh dari Zakat Infaq dan Sadaqah (ZIS) maupun dana tidak langsung lainnya seperti investasi. Untuk memperlancar strateginya ini, yayasan memanfaatkan jaringan alumni di dalam dan di luar negeri, khususnya mereka yang berprofesi sebagai pengusaha. Untuk melaksanakan tugasnya, yayasan membentuk bagian-bagian, antara lain bagian pemeliharaan dan pertanian, yang bertugas memelihara tanah dan lahan pertanian serta mengelola hasilnya. Bagian kedua adalah berkenaan dengan perluasan dan peralatan yang bertugas menangani usaha-usaha perluasan wakaf dan mengurus status hukum dan administrasi pertanahannya. Bagian ketiga adalah berkenaan dengan pergedungan dan peralatan dan bertanggung jawab memelihara dan menambah sarana pergedungan dan peralatan untuk kepentingan pendidikan dan pengajaran.

\footnotetext{
15 Ibid., 285.

16 Ibid., 228.
} 
Berikut rekapitulasi perluasan tanah wakaf PM Gontor yang dilakukan oleh YPPWPM, sebuah yayasan internal Badan Wakaf Gontor khusus membidangi masalah perluasan dan pengembangan wakaf, pada interval tahun 2001-2009. ${ }^{17}$

Tabel 2

Perluasan Tanah Gontor 2001-2009

\begin{tabular}{|c|l|l|l|}
\hline \multirow{2}{*}{ No } & \multirow{2}{*}{ Tahun } & \multicolumn{2}{c|}{ M2 Has Tanah } \\
\cline { 3 - 4 } & & \multicolumn{1}{c|}{ M2 } & \multicolumn{1}{c|}{ Ha } \\
\hline 1 & 2001 & $26.897,00$ & 2,69 \\
\hline 2 & 2002 & $4.249 .786,36$ & 424,98 \\
\hline 3 & 2003 & $82.274,92$ & 8,23 \\
\hline 4 & 2004 & $349.886,28$ & 34,99 \\
\hline 5 & 2005 & $114.040,60$ & 11,40 \\
\hline 6 & 2006 & $8.737,40$ & 0,87 \\
\hline 7 & 2007 & 582,75 & 0,06 \\
\hline 8 & 2008 & $538.972,00$ & 53,90 \\
\hline 9 & 2009 & $1.028 .263,00$ & 102,82 \\
\hline \multicolumn{2}{|c|}{ Jumlah 2001-1009 } & $6.399 .440,31$ & 639,94 \\
\hline \multicolumn{2}{|c|}{ Jumlah Total sampai 2009 } & $8.251 .840,00$ & 825,18 \\
\hline
\end{tabular}

Sampai tahun 2009 ini, luas tanah wakaf dalam hitungan YPPWPM mencapai 825,184 $\mathrm{Ha}$ atau $8.251 .840 \mathrm{~m} 2$, tersebar di 19 kabupaten di seluruh Indonesia. Dengan segala kemampuan yang ada, program perluasan tanah YPPWPM bisa berjalan dengan baik. Perluasan tanah diperoleh melalui penerimaan tanah wakaf dan pembelian tanah baru. ${ }^{18}$

Sedangkan harta wakaf berbentuk sarana dan prasarana lainnya seperti bangunan masjid, asrama, madrasah, kampus dan sebagainya tersebar ke penjuru pondok-pondok cabang Gontor, baik Gontor putra sampai 11 cabang maupun Gontor putri sekitar 5 cabang. Untuk wakaf Pondok Gontor banyak sekali usaha yang telah dilakukan seperti menggarap sawah dengan sistem bagi hasil, investasi melalui unit-unit usaha produktif dan penggalangan dana dengan pola langsung. Usaha paling baru yang dilakukan wakaf Gontor adalah mengembangkan tanaman buah Naga. Buah Naga menjadi salah satu

\footnotetext{
17 Pondok Pesantren Darussalam Gontor, Warta Dunia Pondok Modern Darussalam Gontor, Vol. 62 (Sya'ban, 1430 H), 31.

18 Ibid.
} 
pilihan untuk dikembangkan oleh bagian pertanian YPPWPM di lahan kering yang belum dimanfaatkan secara maksimal. Penanaman buah Naga, pada tahap awal ini, memanfatakan lahan seluas kurang lebih $750 \mathrm{~m} 2$, dengan menggunakan sarana pendukung yang lazim digunakan untuk menanam dan mengembangkan buah Naga. ${ }^{19}$ Khusus untuk unit usaha produktif, wakaf Gontor sampai tahun 2009, telah mendayakan 30 ragam usaha.

\section{Pesantren Wakaf sebagai Model Kemandirian Pesantren}

Secara historis, dinamika pesantren telah diuji melalui keterlibatan mereka dalam peranan-peranan bagi perubahan. Berhubungan dengan kolonialisme dengan model pendidikan Barat, pesantren dengan spirit resistensinya telah berhasil menjaga fungsi-fungsi sosio-kulturalnya. Pesantren tidak hanya sebuah institusi pendidikan tetapi juga institusi pelayanan agama, pelatihan praktis, pengembangan sosial dan juga suatu simbol peradaban Islam. Untuk mendukung fungsi-fungsi dinamis pesantren, tumbuh peranan dasar pesantren. Pesantren mencakup peranan-peranan berikut (1) formal, non-formal dan pendidikan informal dalam lapangan sosial dan agama, (2) jasa sosial melalui aktivitas, konsultasi, kepemimpinan dan pengembangan komunitas, (3) dakwah melalui lembaga, pengajian, dan penyebaran informasi, (4) dedikasi kepada pesantren sebagai sebuah institusi pelayanan dan pengembangan komunitas menekankan kemaslahatan umum di atas kemaslahatan individual, (5) seluruh sistem nilai dan karakter pesantren memberi kemampuan untuk mandiri dan independen atau otonomi.

Kekuatan pesantren yang mendukung eksistensi dan perkembangannya dijaga oleh peran-peran mendasar tersebut. Peranperan dasar seperti lima sifat dan karakter membuat pesantren mampu membangun dinamikanya. Semua itu diperlukan sebagai kekuatan untuk menyaingi nilai-nilai modern. Di samping itu, dinamikadinamika pesantren dapat dilihat secara prinsipil sebagai institusi yang menerima multi-identitas, identitas sosial, identitas kultural, dan identitas spiritual. Dalam menjalankan dinamika ini, pesantren adalah sebuah institusi yang menggabungkan beberapa elemen-elemen kerangka kerja basis berfikir filosofis, motivasi agama, strategi dan pendekatan sosial, dan solidaritas agama komunal. Singkatnya, dinamika-dinamika pesantren melibatkan elemen-elemen internal dan

19 Pondok Pesantren Darussalam Gontor, Warta Dunia Pondok Modern Gontor, Vol. 61 (Sya'ban, 1429 H), 48-49. 
eksternal. Internal bermakna bagaimana memberdayakan motivasi agama, doktrin, dan nilai ideal sebagai sumber warisan tradisi spiritual. Sementara eksternal adalah tantangan-tantangan di sekelilingnya yang memberi stimulan bagi pengembangan pesantren, yaitu modernitas. Yang menjadi tantangan terbesar bagi pesanten dalam konteks dinamis adalah mengembangkan image modern sambil menjaga identitas otentik secara konsisten sebagai warisan tradisi. Peranan fungsi sosio-kultural akan tergantung pada sintesis yang harmonis dari pemberdayaan internal dan eksternal.

Agar pesantren mencapai visi dan misinya sebagai bagian dari masyarakat madani, maka pesantren membutuhkan sumber-sumber daya/dana dalam menopang tujuan luhurnya. Pesantren wakaf, yaitu pesantren yang dibangun dengan kedermawanan atau filantropi Islam berupa institusi wakaf dipandang cukup tepat sebagai model pengembangan kemandirian pesantren di era Indonesia kontemporer. Proses pengembangan pesantren wakaf dapat dilakukan sebagaimana profil dua pesantren di atas dengan beberapa pilar kekuatan pendorong: 1) Adanya pengorbanan yang dilakukan oleh pendiri dan pengasuh pesantren dengan mewakafkan harta miliknya untuk pesantren, 2) Kelembagan pesantren wakaf profesional dalam bentuk badan hukum/yayasan, 3) Pengelolaan aset-aset wakaf secara produktif, dan 4) Penyaluran hasil wakaf baik untuk internal pesantren maupun masyarakat.

Pilar pertama dan utama adalah adanya suri tauladan yang baik dari para pendahulu dan pimpinan pesantren dengan tulus ikhlas mewakafkan sebagian harta miliknya untuk diperuntukkan bagi kemaslahatan umat, yaitu pengembangan pesantren dan tidak sebaliknya diwariskan kepada anak turunnya. Bukti bahwa Hadratus Syaikh Hasyim Asy'ari mewakafkan sekitar 13 ha tanah untuk asrama pesantren dan sawah pada tahun 1947 sebelum beliau wafat telah memberikan sinyal adanya kepentingan yang lebih luhur dibanding lainnya untuk pengembangan dan kemandirian pesantren pada masa depan. Begitu juga dengan pesantren Gontor dengan upaya yang dilakukan tiga pendiri awal yaitu "Trimurti" untuk berikrar mewakafkan tanah pesantren Gontor kepada masyarakat.

Pilar kedua adalah secara kelembagaan pengelola wakaf pesantren harus dilakukan secara professional dan terbuka. Ini dibuktikan pada kedua pesantren telah menunjukkan nâżir wakaf pesantren berupa yayasan atau berbadan hukum yang agaknya berbeda dengan nâżir 
organisasi atau perorangan dalam mengelola wakaf. Nadjib dan alMakassary menyebutkan beberapa kelebihan nâąir yayasan dalam pengelolaan wakaf, di antaranya: pertama, lebih responsif dan implementatif ketika menerima model-model manajemen modern dalam wakaf baik dalam transparansi keuangan, pengambilan kebijakan wakaf, administrasi wakaf, rencana kerja, pergantian kepengurusan maupun dalam mengembangkan aset wakaf dan sumber daya nâżir. Kedua, memiliki kekuatan hukum yang pasti karena disyahkan oleh notaris atau pejabat yang berwenang. Ketiga, sebagai solusi praktis atas adanya konflik kepesantrenan yang bisa saja muncul di kemudian hari. Keempat, ke depan nâz̧ir yayasan dipandang sebagai model ideal dalam kelembagaan pengelolaan wakaf. Yayasan Hasyim Asy'ari PP. Tebuireng dan Badan Wakaf PMDG Ponorogo dengan Yayasan Perluasan dan Pengembangan Wakaf Pondok Modern (YPPWPM) Gontor telah membuktikan bahwa nâżir yayasan dalam mengelola wakaf lebih tepat dan akseptebel di lingkungan masyarakat pesantren. ${ }^{20}$

Pilar ketiga adalah dengan melakukan pengelolaan wakaf secara produktif. Hal ini dicontohkan sangat menarik dalam menggalang wâqif baru berupa perusahaan oleh nâz̧ir wakaf Tebuireng, karena ada program penanaman tanaman sengon pada tanah wakaf pesantren dan untuk memproduktifkannya, maka nâżir wakaf Pesantren Tebuireng berkerja sama dengan salah satu perusahan asal Pasuruan yang konsen terhadap penanaman pohon Sengon ini dan bisa disepakati. Begitu juga dalam program intensifikasi pertanian di wakaf Tebuireng juga berlangsung baik. Sedangkan dalam badan wakaf Gontor, kerjasama dengan perusahaan pernah dilakukan dan contoh yang terakhir adalah tahun 2008 melalui YPPWPM membuka lahan dan menanam kelapa Sawit di Jambi. YPPWPM telah membeli tanah hak milik adat (yang telah lama dimiliki oleh seorang pengusaha) di lokasi yang berada di daerah Jambi dengan luas 300 ha milik Pondok Modern Gontor. Tanah tersebut dibeli oleh Badan Wakaf Gontor secara tunai. Sistem pengelolaan lahan tersebut, dilakukan dengan pola kerjasama borongan, dengan seorang pengusaha yang telah memiliki izin usaha dan mampu mengelola secara profesional. Pola tersebut disepakati dengan perjanjian awal, bahwa pihak pengelola ataupun pemborong bersedia

${ }^{20}$ Nadjib \& al-Makassary, Wakaf, 140-141. 
untuk mengganti biaya garap, jika ternyata di kemudian hari mengalami kegagalan panen atau tidak berubah. ${ }^{21}$

Strategi pengembangan produktivitas pengelolaan wakaf di kedua pesantren juga dilakukan dengan cara membangun unit usaha ekonomi produktif dari harta wakaf yang menghasilkan pendapatan bagi pesantren. Pengembangan pendapatan dilakukan lewat penjualan produk, pelayanan jasa profesional, penyewaaan sarana dan prasarana fasilitas, pengembangan dana abadi dan investasi dari harta-harta wakaf yang ada. Nâżir wakaf Tebuireng telah melaksanakan program seperti ini seperti pemberdayaan aset wakaf berupa sawah dan tanah dengan mencoba meningkatkan hasil dengan berbagai model produktivitas daya wakaf. Begitu juga dengan program sengonisasi dan dilahirkannya Perseroaan Terbatas (PT) atas nama Pesantren Tebuireng yang pada intinya bertugas mengembangkan sumber dana wakaf pesantren. Untuk wakaf Pondok Gontor banyak sekali usaha yang telah dilakukan seperti menggarap sawah dengan sistem bagi hasil, investasi melalui unit-unit usaha produktif dan penggalangan dana dengan pola langsung. Usaha paling baru yang dilakukan wakaf Gontor adalah mengembangkan tanaman buah Naga. Buah Naga menjadi salah satu pilihan untuk dikembangkan oleh bagian pertanian YPPWPM di lahan kering yang belum termanfaatkan secara maksimal. Penanaman buah Naga, pada tahap awal ini, memanfaatkan lahan seluas kurang lebih $750 \mathrm{~m} 2$, dengan menggunakan sarana pendukung yang lazim digunakan untuk menanam dan mengembangkan buah Naga. ${ }^{22}$ Khusus untuk unit usaha produktif, wakaf Gontor sampai tahun 2009, telah mendayakan 30 ragam usaha, seperti, ${ }^{23}$ berikut ragam usaha produktif dalam unit kopontren Gontor.

Tabel 3

Ragam Unit Pengembangan Usaha Gontor

\begin{tabular}{|c|l|c|l|}
\hline No & \multicolumn{1}{|c|}{ Nama Unit Usaha } & Tahun Berdiri & \multicolumn{1}{|c|}{ Letak } \\
\hline 1 & Penggilingan Padi & 1970 & Desa Gontor \\
\hline 2 & Percetakan Darussalam & 1983 & - \\
\hline 3 & Toko Kelontong KUK & 1985 & Desa Bajang \\
\hline
\end{tabular}

21 Gontor, Warta Dunia, Vol. 61, 48.

22 Ibid., 48-49.

${ }^{23}$ Gontor, Warta Dunia, Vol. 62, 31-32. 


\begin{tabular}{|c|l|c|l|}
\hline 4 & Toko Bahan Bangunan & 1988 & - \\
\hline 5 & Took Buku & 1989 & Ponorogo \\
\hline 6 & Warung Bakso & 1990 & - \\
\hline 7 & Fotocopy I KUK & 1990 & Desa Bajang \\
\hline 8 & UKK & 1990 & Desa Gontor \\
\hline 9 & Apotek La Tansa & 1991 & - \\
\hline 10 & Wartel Gambia Permai & 1991 & - \\
\hline 11 & Pabrik Es Balok & 1996 & - \\
\hline 12 & Perkulakan & 1997 & - \\
\hline 13 & Jasa Angkutan & 1998 & - \\
\hline 14 & Wartel Sudan & 1999 & - \\
\hline 15 & Kantin al Azhar & 1999 & - \\
\hline 16 & Computer Jasa & 1999 & - \\
\hline 17 & Wisma Darussalam & 1999 & - \\
\hline 18 & Fotocopy II Asia & 2000 & - \\
\hline 19 & Pasar Grosir & 2002 & Ponorogo \\
\hline 20 & Daruss Distributor Center & 2002 & Mantingan \\
\hline 21 & Pemotongan Ayam & 2002 & Desa Gontor \\
\hline 22 & Pabrik Roti & 2003 & - \\
\hline 23 & Penggemukan Sapi & 2003 & - \\
\hline 24 & Air Minum Kemasan & 2004 & - \\
\hline 25 & Wartel al Azhar & 2004 & Ponorogo \\
\hline 26 & Toko Alat Olah Raga & 2005 & Desa Gontor \\
\hline 27 & Usaha Konveksi & 2006 & - \\
\hline 28 & LM3 & 2006 & Desa Mlarak \\
\hline 29 & Pabrik Mie Ayam & 2007 & Desa Gontor \\
\hline 30 & Teh La Tansa & 2009 & - \\
\hline
\end{tabular}

Pilar keempat yaitu dari hasil pengelolaan aset wakaf maka disalurkan untuk kepentingan masyarakat, baik secara internal untuk pemberdayaan pesantren dalam mengembangkan misi utama pesantren, maupun secara eksternal untuk pemberdayaan masyarakat umum. Pada posisi penyaluran hasil wakaf baik untuk tujuan internal pesantren maupun eksternal, maka pada titik inilah independensi, kemandirian dan kesinambungan pesantren dalam menjalankan misinya bisa diukur pencapaiannya. Kedua profil pesantren wakaf setidaknya membuktikan bahwa keduanya mampu merespons modernisasi dalam berbagai aspek sehingga keduanya relatif dapat 
mengembangkan misi pesantren masing-masing dengan melaui institusi wakaf.

\section{Penutup}

Pesantren bukanlah sejenis institusi pendidikan saja, tetapi lebih bermakna bahwa pesantren memiliki fungsi dan tugas sosio-kultural. Dalam melaksanakan fungsi-fungsi ini, pesantren telah terlibat dalam wacana-wacana modernitas. Modernitas dengan nilai-nilainya memiliki yang dapat saja mempengaruhi nilai-nilai ideal dalam institusi tradisional termasuk pesantren. Pesantren harus memiliki kemampuan untuk menjadi benteng nilai-nilai dalam menghadapi modernitas yang bertujuan untuk merelativitaskan nilai-nilai otentik. Dengan kata lain, pesantren dapat memainkan peranan penting sebagai gerakan spiritual dengan memberdayakan dirinya dalam cara-cara yang kreatif. Dengan memberdayakan fungsi-fungsi sosio-kultural secara keseluruhan, pesantren akan mendidik orang-orang dengan sebuah pendidikan yang holistik.

Untuk pencapaian misi tersebut dibutuhkan kemandirian dan penguatan masyarakat madani bagi civitas pesantren sendiri, dengan membangun model pengembangan pesantren wakaf di era Indonesia kontemporer, yaitu pesantren yang ditopang dengan institusi kedermawanan wakaf dan sekaligus pesantren yang mengembangkan pilar institusi wakaf. Proses pengembangan pesantren wakaf dapat dilakukan beberapa pilar: 1) adanya pengorbanan yang dilakukan oleh pendiri pesantren dengan mewakafkan harta miliknya untuk pesantren, 2) kelembagaan pesantren wakaf profesional dalam badan hukum/yayasan, 3) pengelolaan aset-aset wakaf secara produktif, dan 4) penyaluran hasil wakaf baik untuk internal pesantren maupun masyarakat.

\section{Daftar Rujukan}

Bamualim, Chaider S. \& Abubakar, Irfan (ed.). Revitalisasi Filantropi Islam: Studi Kasus Lembaga Zakat dan Wakaf di Indonesia. Jakarta: PBB UIN Syarif Hidayatullah dan Ford Foundation, 2005.

Bâqî (al), Ibrâhîm Maḥmûd 'Abd. Dawr al-Waqf fì Tanmîyat al-Mujtama' al-Madanî: Namûdhaj al-Amânah al-'Ammah li al-Awqâf bi Dawlah alKuwayt. Kuwait: al-Amânah al-'Âmmah li al-Awqâf Idârat alDirâsah wa al-'Alâqat al-Khârijîyah, 2006.

Gontor, Pondok Modern. Sedjarah Balai Pendidikan Pondok Modern Gontor Ponorogo. Ponorogo: t.p., t.th. 
Gontor, Pondok Pesantren Darussalam. Warta Dunia Pondok Modern Gontor, Vol. 61, Sya'ban 1429 H.

W Warta Dunia Pondok Modern Gontor, Vol. 62, Sya'ban 1430 H.

Halim, A. "Menggali Potensi Ekonomi Pondok Pesantren", dalam A. Halim et al., Manajemen Pesantren. Yogyakarta: Pustaka Pesantren, 2005.

Ismail, SM, et al. (ed.). Dinamika Pesantren dan Madrasah. Yogyakarta: Pustaka Pelajar, 2002.

Kabisi (al), Muhammad Abid Abdullah. Hukum Wakaf. Jakarta: IIMaN Press, 2004.

Nadjib, Tuti A. \& Al-Makassary, Ridwal. Wakaf, Tuban, dan Agenda Kemanusiaan. Jakarta: CSRS UIN Jakarta, 2006.

Qahaf, Mundhîr. al-Waqf al-Islâmî: Tatawwuruh, Idâratuh, Tanmiyatuh. Damaskus: Dâr al-Fikr, 2006.

Shalabî, Muḥammad Muștafâ. Muhâạdarah fì al Waqf wa al-Wasîyah. Iskandarîyah: t.p., 1957.

Tim Penulisan Riwayat Hidup dan Perjuangan K.H. Imam Zarkasyi. Biografi K.H. Imam Zarkasyi: dari Gontor Merintis Pesantren Modern. Ponorogo: Gontor Press, 1996.

Wirosardjono, Soetjipto. The Impact of Pesantren in Education and Community Development in Indonesia. Berlin: Fredrich-Naumann Stiftung Indonesian Society for Pesantren and Community Development (P3M), and Technical University Berlin, 1987. 